\title{
Isotyping paranodal antibodies in inflammatory neuropathies
}

\section{One step closer to precision care}

Cinta Lleixà, BSc, and Luis Querol, MD, PhD

Neurol Neuroimmunol Neuroinflamm 2020;7:e843. doi:10.1212/NXI.0000000000000843

The discovery of autoantibodies against paranodal proteins such as neurofascin-155 (NF155), contactin-1 (CNTN1), or contactin-associated protein-1 (CASPR1) in inflammatory neuropathies has led to the description of subsets of patients with specific phenotypic features. ${ }^{1}$ These antibodies mostly belong to the immunoglobulin $\mathrm{G}$ (IgG) 4 subclass, but IgG1, IgG2, or IgG3 autoantibodies have also been described. ${ }^{2-4}$ Different autoantibody isotypes are associated with different effector mechanisms causing nerve damage ${ }^{5,6}$; testing them may have implications to inform therapeutic choices or to predict prognosis.

In this issue of Neurology: Neuroimmunology \& Neuroinflammation, an article entitled Antiparanodal antibodies and IgG subclasses in acute autoimmune neuropathy ${ }^{7}$ by Luise Appeltshauser et al. provides evidence that IgG2/3 antibodies can be found in acute onset inflammatory neuropathies associated with paranodal antibodies and suggests a correlation between the clinical features and therapeutic response and the IgG isotypes associated to the disease.

The authors screened for anti-CNTN1 and anti-CASPR1 antibodies in a cohort of patients with Guillain-Barré syndrome (GBS) and acute chronic inflammatory demyelinating polyradiculoneuropathy (A-CIDP), including follow-up autoantibody testing in some patients. The frequency of the detected antibodies (around 4\% of GBS/A-CIDP patients) confirms data from previous reports published by this and other groups. They found 5 patients with IgG2 or IgG3 autoantibodies against CNTN1, CASPR1, or both proteins, and 1 patient with IgG4 autoantibodies against CNTN1 and suggest that IgG3 antibodies may associate with a better response to IVIg. A recent study in CIDP does not find a relationship of IVIg efficacy and terminal complement inhibition in CIDP without paranodal antibodies. ${ }^{8}$ However, the authors of this study have previously reported that complement deposition mediated by IgG3 autoantibodies targeting paranodal proteins can be modulated by IVIg. ${ }^{6}$ Thus, the mechanisms through which IVIg exert their effect in CIDP may differ depending on the subtype of CIDP and associated autoantibodies. Other mechanisms may explain the poorer response to IVIg in diseases caused by autoantibodies of the IgG4 isotype. For example, IgG4-producing plasma cells have been reported to have regulatory phenotypes ( $\mathrm{IL10+}$ ) and lower expression levels of the inhibitory immunoglobulin receptor FcGRIIb. ${ }^{9}$ Further studies should clarify the underlying mechanisms explaining this differential response to IVIg of autoimmune diseases depending on the autoantibody isotype; apart from the role of complement inhibition induced by IVIg proposed by the authors, it seems reasonable to assume that the antibody-producing cells that produce antibodies that have antagonistic functions (i.e., proinflammatory IgG1-3 vs anti-inflammatory IgG4) may respond differently to the immunomodulatory effects of IVIg.

The authors also describe an interesting patient with A-CIDP in which the autoantibody subclass switches from IgG3 in the acute phase of the disease to IgG4 in the chronic stage; the target of the autoantibody also shifts over time from CNTN1 and CASPR1 to CASPR1 alone. This simultaneous change in the antigenic target and the isotype, which should be confirmed in

\author{
Correspondence \\ Dr. Querol \\ lquerol@santpau.cat
}

\section{RELATED ARTICLE}

Antiparanodal antibodies and IgG subclasses in acute autoimmune neuropathy

Page e817

From the Neuromuscular Diseases Unit (C.L., L.Q.), Neurology Department, Hospital de la Santa Creu I Sant Pau, Barcelona; and Centro para la Investigación Biomédica en Red en Enfermedades Raras (C.L., L.Q.), CIBERER, Madrid, Spain.

Go to Neurology.org/NN for full disclosures. Funding information is provided the end of the article.

This is an open access article distributed under the terms of the Creative Commons Attribution-NonCommercial-NoDerivatives License 4.0 (CC BY-NC-ND), which permits downloading and sharing the work, provided it is properly cited. The work cannot be changed in any way or used commercially without permission from the journal. 
other patients, may be explained by 2 related facts: first, IgG4 antibodies appear late in the immune response, after several rounds of affinity maturation and somatic hypermutation have occurred. ${ }^{10}$ Second, this fine tuning of the affinity may drive the autoantibody response toward the CASPR1 epitope. Whether this epitope is a immunodominant epitope driving the affinity selection in all CIDP patients in which an antiCASPR1 IgG4 response is detected, as it happens in other diseases such as anti-MusK myasthenia gravis, ${ }^{11}$ and whether this phenomenon occurs in other CIDP or GBS patients with anti-CASRP1 antibodies, remains to be elucidated. In most of the studies regarding paranodal antibodies in CIDP, samples were acquired in the chronic phase of the disease, and there are few longitudinal studies in the field. Therefore, data on the appearance and features of paranodal autoantibodies in the acute phase of CIDP are scarce. For this reason, although larger prospective studies are still needed, the association of IgG isotypes and disease progression and treatment response described in this study could be important for optimal patient care in each moment of the disease.

The report also describes 2 patients with antibodies against both CNTN1 and CASPR1 proteins in the acute phase of the disease. There is uncertainty in the field as to whether the immune response in patients with antibodies against the CNTN1/CASPR1 complex is targeting an epitope arising from the binding of both CNTN1 and CASPR1, or separately against each of CNTN1 and CASPR1 proteins. Authors provide descriptive data suggesting that the latter may be happening. Considering the changes that authors report in the antigenic specificity over time in some patients, it could well be that this uncertainty can be clarified by studying longitudinally (as the authors did in this report) the IgG isotypes in all patients and analyzing epitope changes over time in patients previously classified as having antibodies only against the CNTN1/CASPR1 complex. Because technical issues can also explain some of these discrepancies, collaborative, interlaboratory validation studies are needed to elucidate the true antigenic target and assess the diagnostic accuracy of each test in all nodo/paranodal autoantibodies.

In conclusion, detection of antibodies against paranodal proteins, followed by IgG isotype testing in seropositive cases and their longitudinal monitoring during disease course should be considered in the diagnostic workup in inflammatory neuropathies to improve pathophysiologic knowledge, diagnostic accuracy, and treatment selection.

\section{Study funding}

No targeted funding reported.

\section{Disclosure}

The authors report no disclosures relevant to the manuscript. Go to Neurology.org/NN for full disclosures.

\section{References}

1. Pascual-Goñi E, Martín-Aguilar L, Querol L. Autoantibodies in chronic inflammatory demyelinating polyradiculoneuropathy. Curr Opin Neurol 2019;32:651-657.

2. Doppler K, Appeltshauser L, Villmann C, et al. Auto-antibodies to contactinassociated protein 1 (Caspr) in two patients with painful inflammatory neuropathy. Brain 2016;139, 2617-2630.

3. Stengel H, Vural A, Brunder A-M, et al. Anti-pan-neurofascin IgG3 as a marker of fulminant autoimmune neuropathy. Neurol Neuroimmunol Neuroinflamm 2019;6: e603. doi:10.1212/NXI.0000000000000603.

4. Doppler K, Schuster Y, Appeltshauser L, et al. Anti-CNTN1 IgG3 induces acute conduction block and motor deficits in a passive transfer rat model J Neuroinflammation 2019;16:73-13.

5. Manso C, Querol L, Mekaouche M, Illa I, Devaux JJ. Contactin-1 IgG4 antibodies cause paranode dismantling and conduction defects. Brain 2016;139(Pt 6):1700-1712.

6. Appeltshauser L, Weishaupt A, Sommer C, Doppler K. Complement deposition induced by binding of anti-contactin- 1 auto-antibodies is modified by immunoglobulins. Exp Neurol 2017;287:84-90.

7. Appeltshauser L, Brunder A-M, Heinius A, et al. Antiparanodal antibodies and IgG subclasses in acute autoimmune neuropathy. Neurol Neuroimmunol Neuroinflamm 2020;7:e817. doi:10.1212/NXI.0000000000000817.

8. Keller CW, Quast I, Dalakas MC, Lünemann JD. IVIG efficacy in CIDP patients is not associated with terminal complement inhibition. J Neuroimmunol 2019;330:23-27.

9. Van De Veen W, Stanic B, Yaman G, et al. IgG4 production is confined to human IL 10 -producing regulatory $\mathrm{B}$ cells that suppress antigen-specific immune responses. J Allergy Clin Immunol 2013;131:1204-1212.

10. Vidarsson G, Dekkers G, Rispens T. IgG subclasses and allotypes: from structure to effector functions. Front Immunol 2014;5:1-17.

11. Huijbers MG, Vink AF, Niks EH, et al. Longitudinal epitope mapping in MuSK myasthenia gravis: implications for disease severity. J Neuroimmunol 2016;291: $82-88$. 


\title{
Neurology $^{\odot}$ \\ Neuroimmunology \& Neuroinflammation
}

\author{
Isotyping paranodal antibodies in inflammatory neuropathies: One step closer to \\ precision care \\ Cinta Lleixà and Luis Querol \\ Neurol Neuroimmunol Neuroinflamm 2020;7; \\ DOI 10.1212/NXI.0000000000000843
}

This information is current as of July 24, 2020

Neurol Neuroimmunol Neuroinflamm is an official journal of the American Academy of Neurology.

Published since April 2014, it is an open-access, online-only, continuous publication journal. Copyright

Copyright (C) 2020 The Author(s). Published by Wolters Kluwer Health, Inc. on behalf of the American

Academy of Neurology.. All rights reserved. Online ISSN: 2332-7812.

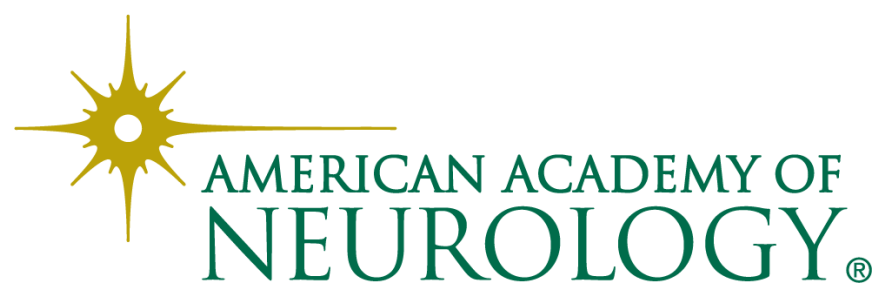




\section{Updated Information \& Services}

References

Subspecialty Collections

Permissions \& Licensing

Reprints including high resolution figures, can be found at:

http://nn.neurology.org/content/7/5/e843.full.html

This article cites 11 articles, 2 of which you can access for free at: http://nn.neurology.org/content/7/5/e843.full.html\#\#ref-list-1

This article, along with others on similar topics, appears in the following collection(s):

\section{All Neuromuscular Disease}

http://nn.neurology.org//cgi/collection/all_neuromuscular_disease Autoimmune diseases

http://nn.neurology.org//cgi/collection/autoimmune_diseases Chronic inflammatory demyelinating polyneuropathy

http://nn.neurology.org//cgi/collection/chronic_inflammatory_demyeli nating_polyneuropathy

Guillain-Barre syndrome

http://nn.neurology.org//cgi/collection/guillainbarre_syndrome Peripheral neuropathy

http://nn.neurology.org//cgi/collection/peripheral_neuropathy

Information about reproducing this article in parts (figures,tables) or in its entirety can be found online at:

http://nn.neurology.org/misc/about.xhtml\#permissions

Information about ordering reprints can be found online:

http://nn.neurology.org/misc/addir.xhtml\#reprintsus

Neurol Neuroimmunol Neuroinflamm is an official journal of the American Academy of Neurology.

Published since April 2014, it is an open-access, online-only, continuous publication journal. Copyright

Copyright $\odot 2020$ The Author(s). Published by Wolters Kluwer Health, Inc. on behalf of the American

Academy of Neurology.. All rights reserved. Online ISSN: 2332-7812.

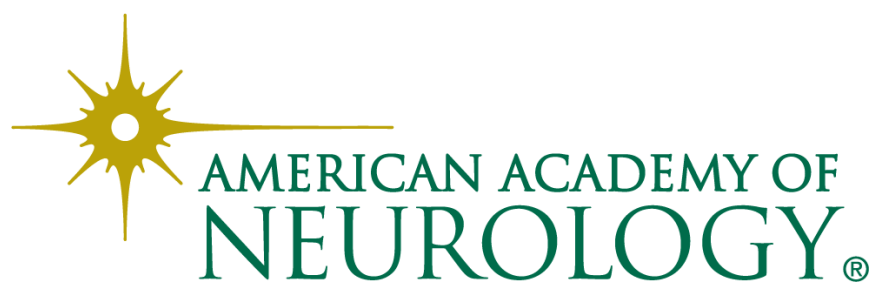

